\title{
MCT1 gene and its relationship with some physiological Variables and lactic acid level after Effort and fatigue for juniors
}

\author{
Dr. Ahmed Helmy Saad ${ }^{(*)}$
}

\begin{abstract}
The study aims to identify the relationship between MCT1 gene and some physiological variables and the level of lactic acid after effort and until fatigue in order to identify the differences between the performance under effort and until fatigue for juniors under the study.

Study sample included 10 juniors from Benha sports club at age stage from 12 to 16 years old .The study used the experimental method, The most important results indicated that there are statistically significant differences between MCT1 gene concentration under effort and until fatigue, as well as the existence of relationship between MCT1 gene concentration and between and some physiological variables, while there was no relationship between the concentration of the gene and the level of lactic acid under effort, while there was a relationship between gene concentration and performance until fatigue.
\end{abstract}

\section{Keywords}

MCT1, Lactate level, physiological variables, Oxygen Uptake, CO2 production, Energy Expenditure.

\section{Introduction and Research problem}

The modern focus in the field of sports is directed towards the possibility of the use of genetics technology to pick out the qualities that entitles its owner to reach the higher levels as well as improving athletic performance

While argues that that molecular biology provide training scientists with a tool enabling them to learn how to control training in the work of gene and how the impact of this training on production of muscle protein, organize and clone the gene expression allowing workers to plan appropriate training programs to improve physical performance. (Bahaa Salama., 2000: pp93)

Maykel.E (2008, pp94) indicated that it is became known that the players who have certain genes are more able to succeed in advanced levels in sports which require excellence in physical and physiological qualities which are closely associated with these genes.

And the molecular biology help us to develop performance levels and help training scientists to understand how to control development of a certain type of protein in the muscle, which helps them to design the most effective training programs to reach the intended training effects .(Abu El-Ela Abdel Fattah., 2003: pp25-26)

Ber Agard.A (2001, pp373) Believes that the feeling of tiredness and physical fatigue depends on the change in the level of The acidity of blood (PH)resulting from the accumulation of lactic acid in the muscles and the body's inability to get rid of it quickly and convert it into energy for use in the effort, which is considered one of the hallmarks of the endurance players, so it was it is necessary to the trainers to take into account raising the efficiency of their athletes by developing their physical and physiological capabilities that enable them to get rid of lactic acid quickly and in optimal way.

Ying ping (2007, pp18) found a close relationship between the appearances of the images genetic MCT1, MCT3, MCT4 and the level of lactate in the blood.

Lecturer, Department of Sport Health Science department Sports College of Physical Education, Benha University 
Tonouchi \& els (2002, pp148) shows that MCT1 gene is responsible for the speed of absorption of lactate in blood and muscle, as well as the process of oxidation of lactic to take advantage of it in the production of new energy compounds showing its impact in sports that last for long periods of time.

As the continuation of the player in performance for long periods with late the emergence fatigue is considered a good indicator of the ability of the athlete, which is evidence of the efficacy of physiological organs, And also refers to the efficiency of the muscles to get rid of lactic acid, which is considered one of the key factors in changing the acidity of the blood which leading to the emergence of fatigue.

From the above the study trying to identify the differences in the concentration of MCT1 gene in some handball beginners and its relationship to some physiological variables and the level of lactic acid after muscle fatigue.

\section{Research objective}

The research aims to identify the concentration of MCT1gene in some handball \& basketball beginners, and its relationship to some physiological variables and the level of lactic acid after muscular fatigue through the identifying: -

- Differences in the concentration of MCT1 gene after effort for (6 min) and until fatigue in some physiological variables and the level of lactic acid for juniors under discussion

- The relationship between the concentration of MCT1 and some physiological variables and the level of lactic acid for the sample under consideration for the performance of effort for (6 min) and the performance till fatigue.

\section{Hypotheses}

- There are significant differences between the performance of effort for $(6 \mathrm{~min})$ and performance till fatigue in the concentration of MCT1 gene and some physiological variables under consideration

- There is a significant correlation between the genetic concentration of MCT1 gene and some physiological variables under consideration for the performance of effort for (6 min) and performance till fatigue.

\section{Research procedures}

\section{Research Methodology}

The researcher used the experimental approach as it suits research nature.

\section{Research sample}

The research sample was selected by intentional method where sample size was 10 handball beginners from Benha sports club, ranged in age from 12:16 years.

Table (1) Personal characteristics for age, length, Weight and BMI and pulse (resteffort) $(\mathrm{M} \pm \mathrm{SD}) \mathrm{N}=10$

\begin{tabular}{l|l|l|l|l}
\hline \hline Variables & mean & median & SD & Skewness \\
\hline \hline age & 14.2 & 14 & 1.14 & -0.478 \\
\hline Length & 1.49 & 1.48 & 0.1 & 0.774 \\
\hline Weight & 39.4 & 37.5 & 11.13 & 1.512 \\
\hline BMI & 17.55 & 16.77 & 3.49 & 0.83 \\
\hline Resting pulse & 75 & 75 & 5.1 & 0 \\
\hline Pulse effort & 175.6 & 176 & 0.52 & -0.484 \\
\hline \hline
\end{tabular}

Table (1) shows mean, and standard deviation of sample under discussion in age, height, weight and body mass index (BMI) and and pulse (rest-effort), where Skewness coefficient ranged between \pm 3 .

\section{Data collection tools and methods \\ Data collection tools}

Determine load intensity on treadmill 
Training load is determined based on body on treadmill (Watt per each $\mathrm{Kg}$ ) so if body weight for player $(80 \mathrm{~kg})$, we begin with load (80 watts) for (2 minutes) and doubles load every two minutes so that it becomes in minute $(3,4)=160$ watts, and $(5,6)=240$ watts $)$ and gradually increase the load until it reaches the individual maximum possible performance load (Elgohari, Y., 2003: pp77-79).

\section{Method of test performing}

The player running on treadmill for continued $(6 \mathrm{~min})$ with the raising of the severity of load by using Novak method then repeat performance again after the full comfort then continue the performance until reaches the stage of fatigue and stop performance .

\section{Measurements used in the study}

\section{Physiological variables}

Oxygen Uptake

$\begin{array}{ll}\text { VO2 } & \mathrm{ml} / \mathrm{min} \\ \text { VCO2 } & \mathrm{ml} / \mathrm{min} \\ \text { VE/VO2 } & 1 / \mathrm{min} \\ \text { VE/VCO2 } & 1 / \mathrm{min} \\ \text { O2exp } & \mathrm{ml} \\ \text { CO2exp } & \mathrm{ml} \\ \text { FiO2 } & \% \\ \mathrm{FiCO} 2 & \% \\ \text { EEm } & \mathrm{Kcal} / \mathrm{min} \\ \text { EEkg } & \mathrm{Kcal} / \text { day }\end{array}$

$\mathrm{CO} 2$ production

ventilatory equivalent for $\mathrm{O} 2$

ventilatory equivalent for $\mathrm{CO} 2$

amount of $\mathrm{O} 2$ with expiratory

amount of $\mathrm{CO} 2$ with expiratory

Inspiratory concentration of $\mathrm{O} 2$

Inspiratory concentration of $\mathrm{CO} 2$

Energy Expenditure

EEkg Kcal/ day

Energy Expenditure pro Kg

\section{Measuring the ratio of lactic acid in the blood (after effort- untill fatigue)}

Lactic acid is measured using a lactate scout machine where there is a Drop of blood is taken on the measurement tape after the effort performance then analyze it, then take another sample until fatigue at duration ranging from 3: 5 minutes

\section{Tools and devices used}

- Restameter attached medical scale to measure height and weight

- Quark Cpet device produced by COSMED company to measure the circulatory and respiratory organs variables with computer attached

- Lactate scout device to measure lactic acid percentage.

- Plastic syringes $(5 \mathrm{~cm})$ and test tube (Edita) to prevent clotting and Coleman to save blood.

- Centrifuge to separate the plasma from the blood cells.

- Thermal Cycler device for DNA analysis.

\section{The main study}

The main study has been applied in the period From 10:22/03/2014 on a sample of 20 players from beginner's handball and basketball at Benha sports club.

Where lactic acid was measured at rest and then measurements of respiratory been applied by using Quark Cpet device in the period From 10: 14/03/2014, in the Physiological measurements laboratory at the Faculty of Physical Education, University of Benha and when the players reach to fatigue after the duration of the effort of 3: 5 minutes lactic acid has been analyzed

The blood samples are pulled by a specialist doctor was placed in test tubes by have Edita material to prevent clotting and saved in Coleman sealed contain ice in order to transport them Molecular Biology lab at Faculty of Science University Benha .where DNA bar has been analyzed and measuring the concentration of MCT1gene

The process of DNA extraction and measuring the concentration of MCT1 gene has been stared in the period from 18:22/03/2014 by using the following primer sequence
Forward
5'-AGCAAACGAGCAGAAAAAGG-3'
Reverse
5'-CTGGGTCATGAACTGCTCAA-3' 


\section{DNA separation steps}

$1 \mathrm{ml}$ of blood placed in a tube and then $1 \mathrm{mmol}$ Lysis solution to break the membrane protein and then mixture shaken until it is mixed and then tube put inside water bath at $60^{\circ}$ temperature for two hours, then phenol substance added for cleansing and then shaken for 5 min and placed in a centrifuge for $10-15 \mathrm{~min}$ at $5000 \mathrm{round} / \mathrm{min}$, then chloroform is put on the mixture resulting from the separation process and then shaken for $5 \mathrm{~min}$ and then placed in a centrifuge for $10-15 \mathrm{~min}$ at $5000 \mathrm{round} / \mathrm{min}$ and upper layer of the mixture extracted from centrifugation device transferred to a new tube then ethanol added for cleanse and then placed in $20^{\circ}$ temperature for 24 hours and put the tube in a centrifuge for $15 \mathrm{~min}$ at 5000 round $/ \mathrm{min}$ and then ethanol in the tube disposed of and tubes left open in a well-ventilated place until it is dry and then $30-40 \mathrm{mmol}$ of distilled water put inside the tube and the tube is closed and shaken for $5 \mathrm{~min}$

\section{Results}

\section{First hypothesis result}

\section{Second hypothesis result}

Table (4) Spearman correlation between genetic concentration of MCT1 gene, physiological variables and the concentration of lactic acid after the effort and until fatigue $\mathrm{N}=10$

\begin{tabular}{|c|c|c|c|}
\hline \multirow[b]{2}{*}{ Variables } & \multirow[b]{2}{*}{ unit } & \multicolumn{2}{|c|}{ Spearman Correlation } \\
\hline & & $\begin{array}{l}\text { After effort } \\
(6 \mathrm{~min})\end{array}$ & $\begin{array}{l}\text { Until } \\
\text { fatigue }\end{array}$ \\
\hline Oxygen Uptake & $\mathrm{ml} / \mathrm{min}$ & 0.584 & $-0.855^{*}$ \\
\hline $\mathrm{CO} 2$ production & $\mathrm{ml} / \mathrm{min}$ & 0.243 & $-0.721 *$ \\
\hline ventilatory equivalent for $\mathrm{O} 2$ & $1 / \mathrm{min}$ & -0.158 & 0.552 \\
\hline ventilatory equivalent for $\mathrm{CO} 2$ & $1 / \mathrm{min}$ & $0.997 *$ & $0.830^{*}$ \\
\hline amount of $\mathrm{O} 2$ with expiratory & $\mathrm{ml}$ & 0.62 & $-0.830 *$ \\
\hline amount of $\mathrm{CO} 2$ with expiratory & $\mathrm{ml}$ & $-0.821 *$ & $-0.855^{*}$ \\
\hline Inspiratory concentration of $\mathrm{O} 2$ & $\%$ & $-0.838^{*}$ & $-0.869 *$ \\
\hline Inspiratory concentration of $\mathrm{CO} 2$ & $\%$ & -0.419 & 0 \\
\hline Energy Expenditure & Kcal/ min & $0.802 *$ & $-0.842 *$ \\
\hline Energy Expenditure pro $\mathrm{Kg}$ & Kcal/ day & $0.802 *$ & $-0.842 *$ \\
\hline Lactic acid & $\mathrm{Mg} / \mathrm{dl}$ & -0.421 & $0.964 *$ \\
\hline
\end{tabular}

$\mathrm{R}$ indexed value at significance of 0.05 and $\mathrm{DF} 8=0.738$

table (4) shows that there is a strong correlation between the genetic concentration of MCT1 gene and physiological variables and the concentration of lactic acid in performance after the effort and till fatigue at 0.05 level of significance.

\section{Discussion}

\section{Discuss first hypothesis}

Table (2) shows that skewness coefficient of torsion is confined between $-0.74: 1.04$ for the effort for ((6 min)) while confined between -2.07: 1.49 for until fatigue which indicates that the sample is homogeneous in physiological variables under consideration, as well as the concentration of lactic acid and MCT1 gene

As can be seen from Table (3) that there are significant differences between both measurement of effort for a period for $(6 \mathrm{~min})$ and the effort until fatigue in all physiological variables under consideration beside in the concentration of lactic acid and Jane MCT1 where the differences were in favor of the effort until fatigue in each of maximum oxygen consumption and carbon dioxide product, and pulmonary ventilation of oxygen and carbon dioxide and oxygen and exhale with energy consumed per minute and energy consumed/kg. 
While the differences were in favor of the effort for $(6 \mathrm{~min})$ in the outgoing carbon dioxide with Exhalation variables and the concentration of oxygen in the inhalation and the concentration of carbon dioxide in the inhalation.

The increase of physiological variables during performance till fatigue is due to all devices operate at maximum capacity to be able to provide the amount of oxygen and food necessary for the performance in addition to ridding the muscles and cells of the residue of energy production

Increase remain standing until the devices fail to provide the muscles and cells need of oxygen and so, muscle here rely on anaerobic activity, which leaves the blood lactate .Hence With the failure of the body to use lactate and converting it into energy player stop performance and reach up to the peak of fatigue

Table (3) indicated that there are statistically significant differences in favor of performance till the fatigue in the concentration of lactic acid concentration and MCT1 gene.

Where Blegaard \& etal (1999, pp255) indicate that the concentration of both muscles and blood lactate decreases by increasing the concentration of MCT1 gene Therefore, the ratio of muscle and blood lactate is another associated with the increase in MCT1.

\section{Discuss second hypothesis}

Table (4) shows that the value of $t$ is confined between 0.802: 0.997 for the performance of $(6 \mathrm{~min})$ at the level of significance 0.05 ,where it's value was greater than the value of tabulated $t$ which shows a strong correlation between the concentration of MCT1 gene and both of pulmonary ventilation to carbon dioxide and outgoing carbon dioxide with Exhalation and oxygen concentration in inhalation and the consumed energy per minute and energy consumed / $\mathrm{kg}$ in the case of the effort for a period of (6 min), while there is no any differences in the rest of the variables and the concentration of lactic acid

While the value of calculated t confined between 0.721: 0.964 for performance until fatigue where it's value was greater than the value of tabulated t at the level of significance 0.05 which indicating the existence of a correlation between the concentration of MCT1 gene and all physiological variables and the concentration of lactic acid except pulmonary ventilation of oxygen and concentration carbon dioxide in inhalation there wasn't any significant correlation.

Where Bentley DJ \& etal (2009, pp38) indicates that there is a relationship between the ratio of lactic acid and the appearance of MCT1 gene beside a relationship between MCT4 the amount of energy produced during a performance and maximum consumption of oxygen, which indicate that there is a significant effect between the emergence of gene expression for MCT1 and MCT4 genetic forms and between performance cycle and which is positively correlated to the increase of length and intensity of physical exertion.

These results are in agreement with Bickham \& etal (2006), Harley YX \& etal (2009), Cupeiro R \& etal (2010), Green HJ \& etal (2011), Neal CM \& etal (2013), Sawczuk M \& etal (2014) ,Benzikan Ben-Zaken S \& etal (2014) and Fedotovskaya \& etal (2014).

\section{Conclusions}

- There are significant differences between the performance with effort for $(6 \mathrm{~min})$ and performance till fatigue in physiological variables under consideration.

- There are significant differences between the performance with effort for $(6 \mathrm{~min})$ and performance until fatigue in the concentration of lactic acid and MCT1 gene concentration.

- There is correlation between the concentration of MCT1 gene and pulmonary ventilation variables for carbon dioxide and carbon dioxide out going with Exhalation exhaled with the concentration of oxygen in the inhalation and energy consumed per minute and energy consumed / $\mathrm{kg}$ in the case of the effort for a period of $(6 \mathrm{~min})$.

- There is correlation between the concentration of MCT1 gene and some physiological variables and the concentration of lactic acid in the case of performance till fatigue 


\section{Recommendations}

- Attention to training beginners on bearing performance to be able to continue on making effort for the most possible long period and delay the onset of fatigue.

- Picking the beginners who have an abundance of produce MCT1 gene because of its significant effects on reducing the concentration of lactic acid and late-onset fatigue

- Study of Other genetic images of the same gene, such as Jane MCT3 and MCT4.

- The need to create a molecular biology labs to conduct genetic testing and studies to use it in the selection process.

\section{References}

Abul EL-Ela Ahmed Abdel Fattah (2003): physiology and sports training, 1st edition , Arab Thought house, Cairo. (in Arabic language)

Bahaa Eddin Ibrahim Salama (2000): Sports Physiology and physical performance ( blood lactate ), 1st ed., Arab Thought House , Cairo . (in Arabic language)

Hussein Heshmat and Nader Mohamed Shalaby (2003): Physiology of muscle fatigue, the center of the book for publication, Cairo,. (in Arabic language)

Bentley DJ, Roels B, Thomas C, Ives R, Mercier J, Millet G, Cameron-Smith D. (2009): The relationship between monocarboxylate transporters 1.4 expression in skeletal muscle and endurance performance in athletes. Eur J Appl Physiol. Jun;106(3):46571.doi:10.1007/s00421-009-1034-5.

Ben-Zaken S, Eliakim A, Nemet D, Rabinovich M, Kassem E, Meckel Y. (2014): Differences in MCT1 A1470T polymorphism prevalence between runners and swimmers. Scand J Med Sci Sports. Apr 7. doi: 10.1111/sms.12226.

Ber Agard.A., (2001): lapin got Williams American cloudy. acmes advanced exercise physiology.

Bickham DC, Bentley DJ, Le Rossignol PF, Cameron-Smith D. (2006): the effects of shortterm sprint training on MCT expression in moderately endurance-trained runners. Eur $\mathbf{J}$ Appl Physiol. Apr;96(6):636-43.

Cupeiro R, Benito PJ, Maffulli N, Calderón FJ, González-Lamuño D. (2010): MCT1 genetic polymorphism influence in high intensity circuit training. J Sci Med Sport. Sep;13(5):526-30.doi: 10.1016/j.jsams.

Cupeiro R, González-Lamuño D, Amigo T, Peinado AB, Ruiz JR, Ortega FB, Benito PJ. (2012): Influence of the MCT1-T1470A polymorphism (rs1049434) on blood lactate accumulation during different circuit weight trainings in men and women. J Sci Med Sport. Nov;15(6):541-7. doi:10.1016/j.jsams.

Elgohari, Y. (2003): Quantitative and qualitative corporale, kardiozirku- latorische, kardiorespiratorische und metabolische Reaktionen von Männern bei/nach erschöpfenden Spiroergometrien in Abhängigkeit vom Trainingszustand, der Sportart sowie unterschiedlichen Belastungsmethoden, Inaug. Diss. (Dr. Phil.), Justus-LiebigUniversität Gießen, , S. 77-79.

Fedotovskaya ON, Mustafina LJ, Popov DV, Vinogradova OL, Ahmetov II. (2014): A common polymorphism of the MCT1 gene and athletic performance. Int J Sports Physiol Perform. Jan;9(1):173-80. doi: 10.1123

Green HJ, Duhamel TA, Smith IC, Rich SM, Thomas MM, Ouyang J, Yau JE. (2011): Muscle metabolic, enzymatic and transporter responses to a session of prolonged cycling. Eur J ApplPhysiol. May;111(5):827-37.doi:10.1007/s00421-010-1709.

Harley YX, Kohn TA, St Clair Gibson A, Noakes TD, Collins M. (2009): Skeletal muscle monocarboxylate transporter content is not different between black and white runners. Eur J Appl Physiol. Mar;105(4):623-32. doi: 10.1007/s00421-008-0942-0.

Holger M. Becker. (2005): transport activity of mot1 expressed in xonopus oocytes is increased by nteraction with cabonic anhydrase. J. boil. Chem, vol. 280, issye 48. 
Maykel England., (2008): adaptations to swimming training in fluency of training volume.med sic sports exercise.

Montgomery. h \& Boyne. (2004): equine and comparative. Exercise physiology. Vol. 1,n.4..

Neal CM, Hunter AM, Brennan L, O'Sullivan A, Hamilton DL, De Vito G, Galloway SD. (2013): Six weeks of a polarized training-intensity distribution leads to greater physiological and performance adaptations than a threshold model in trained cyclists. $\mathbf{J}$ Appl Physiol. May 15;114(10):1490.

Sawczuk M, Banting LK2, Cięszczyk P3, Maciejewska-Karłowska A1, Zarębska A4, Leońska-Duniec A3, Jastrzębski Z4, Bishop DJ2,Eynon N5. (2014): MCT1 A1470T: A novel polymorphism for sprint performance?. J Sci Med Sport. Jan 1. pii: S14402440(13)00525-2. doi: 10.1016/j.jsams.2013.12.008.

Tonouchi. M, Hatta. H and Bonen. A. (2002): muscle contraction increase lactate transport while reducing sarcolemmal mct4 but not mct1.am j physiol endocrinol melab.

Ying ping Huang, Tao Xiao and Yehong Liang. (2007): progress in study of exercise , monocarboxylate transporter 1 and lactic shuttle. Physical education university Zhengzhou. Henan 056038 china.. 